\title{
Observatory's linguistic landscape: semiotic appropriation and the reinvention of space
}

\author{
Amiena Peck and Felix Banda
}

\begin{abstract}
Using a longitudinal ethnographic study of the linguistic landscape (LL) in Observatory's business corridor of Lower Main Road, the paper explores changes brought about by the influx of immigrant Africans, their artefacts and language practices. The paper uses the changes in the LL over time and the development of an "African Corner" within Lower Main Road, to illustrate the appropriation of space and the unpredictability, which comes along with highly mobile, technological and multicultural citizens. It is argued that changes in the LL are part of the act of claiming and appropriating space wherein space becomes summarily recontexualized and hence reinvented and "owned" by new actors. It is also argued that space ownership can be concealed through what we have called "brand anonymity" strategies in which the identity of the owner is deliberately concealed behind global brands. We conclude that space is pliable and mobile, and that, it is the people within space who carve out new social practices in their appropriated space.
\end{abstract}

\section{Introduction}

The neighbourhood of Observatory in Cape Town (South Africa) is one which offers a microcosm of multicultural agents, activities and practices in late modern South Africa. Although Dutch settlement in the Cape started in 1652 with the arrival of Jan van Riebeeck, extensive documentation of Observatory starts from early 1900s, thereafter followed by colonial occupation by the British. Evidence of Dutch colonialism is immortalised by the name "Liesbeek" Parkway indelibly etched on one of the main highways in Cape Town. The British later colonized the Cape as well, and it is at this point that John Young recounts the history of urban Observatory as commencing with massive in-migration from Britain:

Most of the immigrants who came to Observatory were British lower middle-class, shop- keepers, artisans and clerks. They made Observatory into a colonial home from-home, copying many of the conventions and mores of the English bourgeoisie. $(1998,63)$

At this point, there were large numbers of immigrants residing in Observatory, which included amongst others: Lithuanians and Jews. During this time, the area still permitted

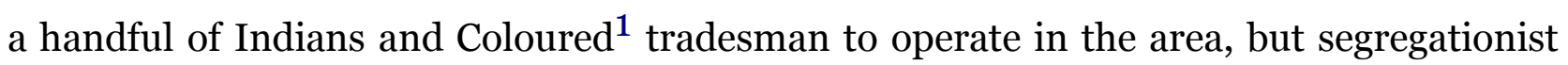


policies were already taking shape. Young $(1998,38)$ states that "By 1910 applications for trading licences under the General Dealers' Act of 1906 from persons with Muslim names were routinely denied." The non-Asiatic law seriously impacted Indian and Muslim tradesmen and eventually led them to having to sell their shops and move out of the area. This oppressive law was consistent with other racially discriminate laws, which were to be promulgated during apartheid. With apartheid coming into effect in 1948 and thereafter legislated with the enactment of the Group Areas act of 1950, areas were divided into "white", "coloured", "Indian" and "black" areas.

Observatory became officially known as a designated white suburb under the Groups Areas Act (as amended in 1966). However, unlike other white areas which were Afrikaans dominant, Observatory remained largely English. The reason for much of Cape town originally being pro-British (and hence English-dominant) may well have stemmed from the role that the British army played in fighting in the anti-Boer war in 1899-1902, coupled with post-epidemic "cleansing" of the city and "civilizing" sensibilities of the British empire, which saw most of the Afrikaaners pushed out of the Southern suburbs, including Observatory (cf. Bickford-Smith, van Heyningen, and Worden 1999).

Arguably, Cape Town has been in a constant state of transformation for as long as can be remembered and that transformation has occurred, and continues to occur primarily through translocalizations and transnational cultural flows. Mignolo (2000, 236) posits that "the current process of globalization is not a new phenomenon, although the way in which it is taking place is without precedent". Previously, translocal and transnational cultural flows were blatantly visible through the importation of slaves to the Cape during the era of colonialism. However, today we talk about the influx of these flows largely brought about through other means like technologies and migration.

In the 2011 national census survey, Observatory was included in Ward 057 along with areas such as Gardens, Mowbray, Salt River, Vredehoek, Woodstock and Zonnebloem. Due to the lack of specificity regarding Observatory in the 2011 census however, this paper draws on Census 2001 to portray an adequate picture of the sociocultural make-up. In the 2001 Census the White populace make up more than half of the population with (57.42\%), followed by Black/African (20.28\%), Coloured (19.87\%) and Indian/Asian (3.5\%). Half (50.56\%) of the population are aged between 18 and 34 and a quarter (25.03\%) of the population are between the ages of 35-54. The very young ranging from $0-17(10.91 \%)$ and the elderly ranging from $55^{-65}+(13.46 \%)$ make up the final quarter with (24.37\%). This representation is consistent with the "young" vibe catered for by clubs/pubs and student hostels in Observatory.

Observatory's semiotic landscape has gone through many transnational changes, and traces of the different languages and communities have endured on the landscape. Victorian-styled buildings and narrow roads index a bygone colonial period. The arrival of European settlers can be ascertained as the catalyst of turbulence which is still today present on Observatory's linguistic landscape (LL). It is argued that, over time signage on these buildings have come to reflect the burgeoning African locality which has brought about Observatory's African appeal. Due to the artistic and bohemian reputation that Observatory has also become known for, this neighbourhood has been compared to the 
upmarket artistic neighbourhoods of Soho in New York and Notting Hill in London (Peck 2012).

Signage on Observatory's commercial hub of Lower Main Road (henceforth LMR) is of particular interest due to its regular turnover of stores and intriguing and creative appropriation of world languages and global cuisines. Pertinently, while some studies have looked at signs on the LL as reflective of diverse linguistic repertoires (cf. Backhaus 2007); it is argued in this article that signs on the LL can also play a symbolic role wherein appropriation, aspiration, transgression and hybridity are found to be indicators of changes in the social milieu. In addition, the emplacement of signs is also critical to understanding spatial "ownership", power relations and interpretation of fissures and contradictions in social structure. For this purpose, space, artefacts and texts are not viewed as static elements of the LL, but are seen as mobile and constantly open to resemiotization and recontextualization.

Iedema $(2003,50)$ talks about resemiotization of signage as “...the social unfolding of the processes and logics of representing...It is from this socially situated vantage point that the resemiotization problematic gains its significance." Changes to the external aesthetics are understood as the resemiotization of the multimodal appearance over time. Iedema's $(2003,40)$ resemiotization of signage and space concerns: “...how meaning making shifts from context to context, from practice to practice, or from one stage of a practice to the next”. In this way, resemiotization is not seen as divested of multimodality, but rather as a complementing factor which expands on changes in multimodality over time. Different signs on the LL which feed into the neighbourhood's "alternative", "cosmopolitan", and "African" and "edgy" feel are unpacked here. The LL is thus analysed in its capacity to capture the appropriation and transformation of signs in (claimed) space as they traverse through time and across sociocultural and even national borders.

\section{Linguistic landscape studies}

Here we use a well-known and comprehensive definition of linguistic landscape as defined by Landry and Bourhis $(1997,25)$ to encompass:

The language of public road signs, advertising billboards, street names, place names, commercial shop signs, and public signs of government buildings combines to form the linguistic landscape of a given territory, region, or urban agglomeration

On the LL we find that language ideology is depicted by "...the visibility and salience of languages on public and commercial signs in a given territory or region" (Landry and Bourhis 1997, 23). In this regard, focus is placed on languages that feature prominently, occasionally and those that are completely absent from the LL. In this way, linguistic appropriation of space is extremely important in its capacity to highlight issues surrounding cultural and symbolic value.

When analysing the largely "Africanized" signs on the LL in Observatory's commercial corridor, questions into the symbolic value of these artefacts and texts as well as the appropriation of space are investigated. The importance of text on the urban landscape 
can be cushioned by larger sociopolitical and economic factors. Leeman and Modan $(2010,182)$ elucidate this point when they declare "[B]ecause words on the street are part and parcel of the texture of urban landscapes, a full understanding of any urban linguistic landscape must be undergirded by in-depth knowledge of the ways in which cities themselves are shaped." Thus, we show how the influx of Black business owners and patrons, since 1994, has changed the shape of Observatory in many ways including the visibility of languages other than English and the invisibility of Afrikaans, the coofficial language during apartheid.

The public space according to Shohamy and others is constituted by "...streets, parks, billboards, shops, stores and offices. The core of the public space in the era, however, consists principally of areas designated as 'center' or 'downtown', i.e. the groups of streets and squares where one sees 'a crowd' when most people are not at work" (Shohamy, Ben Rafael, and Barni 2010, xiv). The "core of public space" in Observatory is LMR which is where the hive of convivial practices occurs and where the data originated.

We conceptualize space as not only referring to objects and boundaries but also to language and interactional practices evident in a community (Scollon and Scollon 2003). Thus, the visibility of languages, artefacts, cultural symbols, the kinds of social interaction as well as sociocultural composition of constituencies in a specific area constitute the space. However, Leeman and Modan (2010) sagely caution that it should not be assumed (as often happens in LL research) that the audience is made up of people who can read and interpret the language and signage "correctly" or as intended by the signmaker. Their work on Chinatown in Washington DC is particularly insightful as it reveals the transformation of "Chinese" signage overtime and speaks to the strategic markers on signage, such as "traditional" colours (red and black) and "bad English". They argue that “... linguistic landscapes, like other landscapes, are subjective representations rather than objective physical environment" (2010,333). In their study, the incorporation of Chinese signs was seen as authenticating a distinctive Chinese ambience associated with Chinatowns.

Moreover, Shohamy and others (2010) assert that despite Landry and Bourhis (1997) and Cooper and Spolsky (1991) advances in this area of research, the dynamics of LL has not been fully unpacked. To this end, they assert that LL “...constitutes a field characterised by dynamics of its own, contingent on the nature of its linguistic, social cultural and political context" (2010, xii). With the exception of a few studies (Leeman and Modan 2010; Lou 2007; Stroud and Mpendukana 2009) LL studies generally have focused on the synchronic capturing and analysis of the LL with a conspicuous dearth of research into the ideological and sociopolitical construction of the landscape over time. In this regard, Stroud and Mpendukana (2009) propose an ethnographic approach to LL, which accounts for both production of signage and reception of messages. This is also in line with Scollon and Scollon's (2003) postulations on geosemiotics, in which emplacement of signage and the dialogicality between the other signs in place are critical components of the analysis. It is not surprising that more recent studies on LL have taken on-board multimodality (Kress and Van Leeuwen 2006) and resemiotization (Iedema 2003) as integral components of the analytical framework (see Jaworksi and Thurlow 2010). Multimodality, seen in this paper as an integral part of the LL, encapsulates the 
different modes, emplacement and other semiotic resources used besides language. Fonts (size and colour) are especially thought of as important parts of the sign as they have the ability of connoting effects of romanticism, edginess and newness.

An analysis of the linguistic landscape should, therefore, establish more than mere heirarchisation (through position and visibility on signs), but rather identify "semiotic resources" which speak to issues involving appropriation, power, preference, inclusion/ exclusion and integration through signage. In this way a LL analysis is useful in creating a more in-depth understanding of this diverse neighbourhood through visual representation on signage over time, an area which has all but been overlooked for a very long time.

\section{Methodology and context}

Data collection began at the end of 2008 and ended in 2011 (with some follow-up data collected in 2012). All data were collected through digital capture of languages and signage. A total of 10 interviews with shop owners, employees and patrons on LMR were conducted to explore how the languages and signage were interpreted and understood over time. Specifically, interviews were conducted with: (1) shop owners/managers at Mr Lin's Sushi and Thai (1), Ezithebeni Braai Lounge (1), VIV supermarket (1); (2) employees at Mr Lin's Sushi and Thai (1), Ezithebeni Braai Lounge (1), African Access (1), VIV supermarket (1); (3) consumers/patrons at Ezithebeni Braai Lounge (2) and VIV supermarket (1).

Permanent public signs (specifically shop windows) on the busiest business stretch of LMR were captured during this time frame. The choice of languages on signs was considered one of the first steps in constructing an image of the neighbourhood and what follows is a quantitative depiction of the landscape. On the commercial corridor of Observatory, a total of 63 signs was noted and tabulated in accordance with the number of languages which were solitary and those in combinations with other languages. The graphic quantification of the linguistic configuration is provided below and offers a mechanistic picture of the languages chosen on permanent public signs:
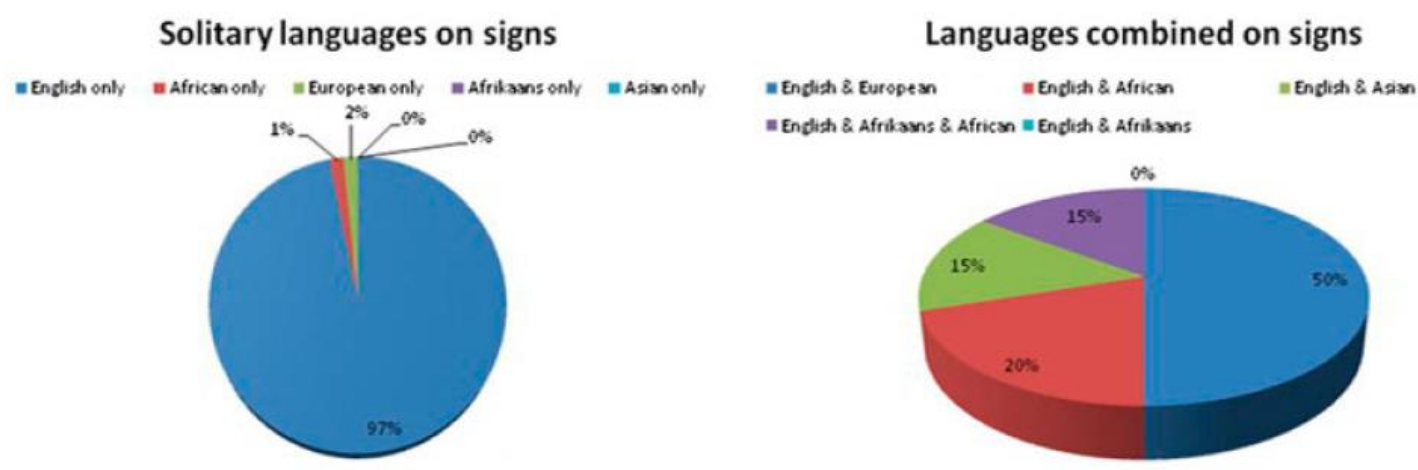

Figure 1. Graphs of visible signs.

Note: Graphs formulated by A. Peck (2010).

The first graph indicates signs which only have one language visible on signs and the second graph reveals languages in combination (and their frequency) on signage in Observatory. For Backhaus (2007), a sign that displays a translation or has been designed in a multilingual format is done so as to accommodate people with a foreign background. 
For Backhaus, the absence of translation on signage in Tokyo Japan indicated that the implied reader was Japanese. We shall argue that this is not necessarily the case with some of the signage in our corpus which appears used for aesthetic and advertising effect only.

\section{Mapping the landscape}

Observatory's city planning and architecture act as the most enduring building blocks of the semiotic landscape and speak to the colonial heritage and apartheid history of the neighbourhood. Moreover, the manner in which new shops and signage become interwoven within this century-old Victorian neighbourhood emerges as a type of resemiotization of Observatory's LMR. The neighbourhood of Observatory is situated favourably with access to the city's major highway and access to train, bus and taxi ranks.

It is also situated a stone's throw away from a well-known state hospital and a short stint from the prestigious and historically white University of Cape Town. Observatory's close proximity to sought-after institutions and the efficient municipal planning identifies it as a previously-white neighbourhood during apartheid. In this way the community configuration also impacted the landscape of Observatory. In fact, Montoya-Pelaez (1987) attributed gentrification in the area largely to the preference of white populace during apartheid:

It was assumed that this group was more responsible for gentrification, because they belong to the wealthier and more privileged sector of this society.... In other words the [property] agents would only allow the "white" members of the population to buy property in Observatory.

From the excerpt there is a sense that whites played a beneficial role in Observatory in that they (purportedly) positively influenced the augmentation of the area and inversely the area benefited from their presence. This belief is indicative of the apartheid indoctrination in which whites were privileged to the best landscapes in the country.

Ironically, Observatory is still reputed to be a neighbourhood which is undergoing massive gentrification (typically seen through the influx of middle-class professionals purchasing large and well-appointed homes in the neighbourhood). Added to Observatory's popularity is its reputation as "African" and (subsequently) "cosmopolitan". The express depiction of an "alternative" African Observatory challenges the earlier argument regarding "ownership" and "rightness" of whites in Observatory. In essence, contemporary Observatory has also opened its landscape to the migration of Africans and to the celebration of Africanism.

During the British colonial period, Observatory's bond with its colonial ruler was adopted with such enthusiasm that the neighbourhood was once called Observe-a-tory. This was a play on the Observatory residents' fervent desire to be affiliated with the British Empire during the time when Britain's conservative party "Tory" was popular. The neologism "Observatorian" (with its obvious link to "Victorian") is a present-day label adopted by some Observatory residents to emphasize their tie to the neighbourhood and can (to some extent) also be arguably seen as a re-affirmation to its British heritage.

\section{http://repository.uwc.ac.za}




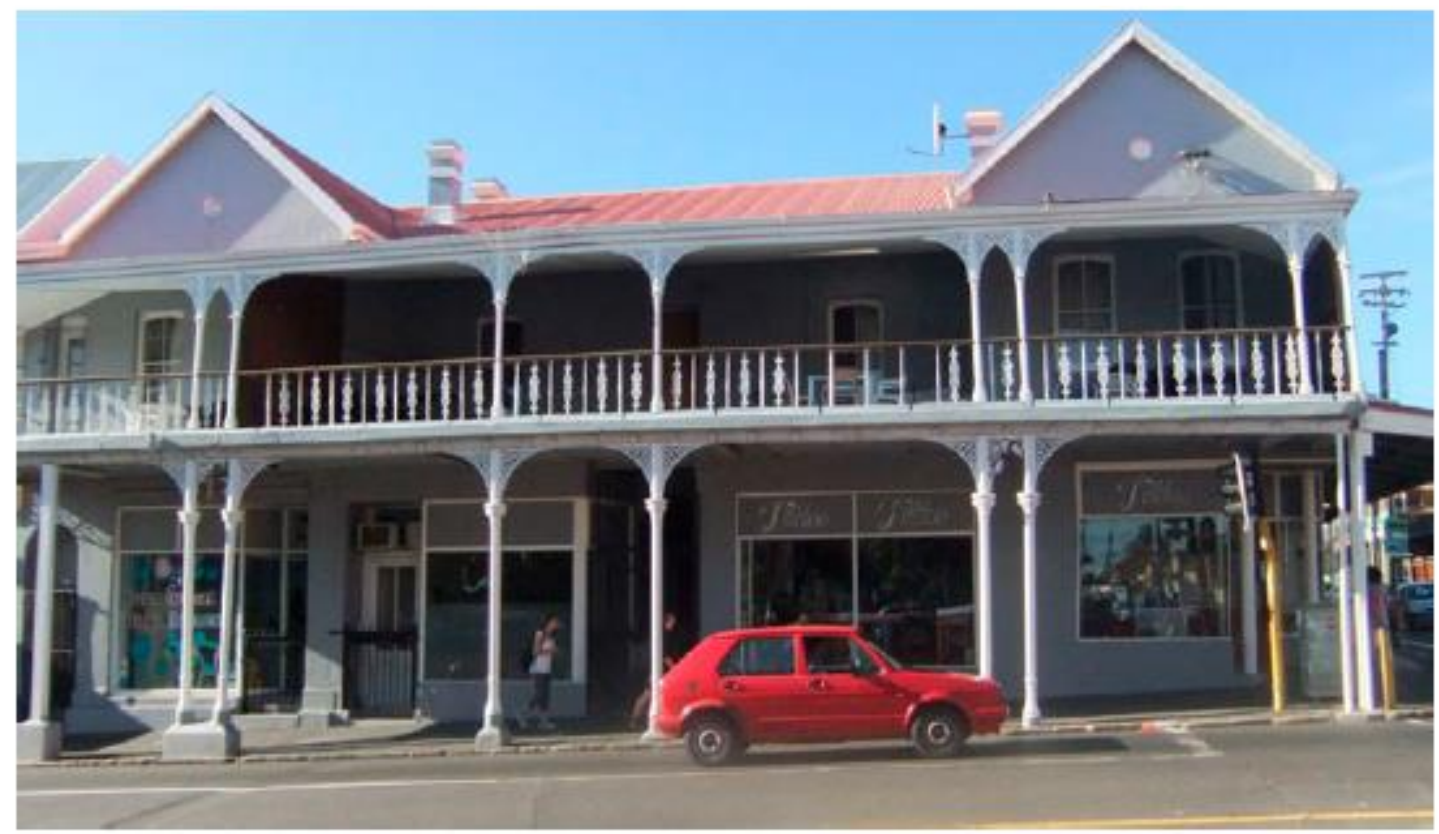

Figure 2. Victorian architecture.

Note: Picture taken by A. Peck (2010).

The tapered balcony and lace-detailed poles are indicative and a reminder of buildings built during the Colonial period. An example of the Victorian buildings is provided on the previous page.

Apart from the century-old Victorian buildings and Cape Dutch Villas, another enduring feature of the LL is the numerous narrow roads. LMR is characteristically commented upon by vexed drivers attempting to navigate through the narrow roads. The roads are barely big enough for two cars to pass by comfortably; however, narrow roads are not a city planning error, but rather further evidence of Observatory's early conception - a time before the invention of cars. Tenably as permanent as the buildings and roads are that of the road names which serve as navigation devices for newcomers and passers-by alike.

Street names as enduring relics of the LL. Although some street names in Observatory are bilingual (English and Afrikaans), there remain nevertheless, aspects of Observatory's colonial past within street names. In Observatory, street names with evidently British and Dutch origins abound. British ones include: "Oxford", "London", "Sussex", "Norfolk", "Rochester" and "Collingwood". Additionally, there are also streets which were named earlier during the time of Dutch colonialism, specifically: Bellevliet, Molenvliet and Coornhoop.

Undoubtedly the most well-known and enduring remnant of colonialism can be seen at the border of Observatory and on one of the major highways in Cape Town, that of "Liesbeek Parkway". The word "Liesbeek" was coined by Jan Van Riebeek and means "sweet water" in Dutch. Historically, the arrival of Jan Van Riebeek in South Africa earmarked the first European colonial entry into the Cape in 1652. He commissioned the building of an Observatory to which the neighbourhood has been named. Liesbeek 
Parkway itself has become a part of the city with it being erected on one of Cape Town's main highways (N2) as seen below:

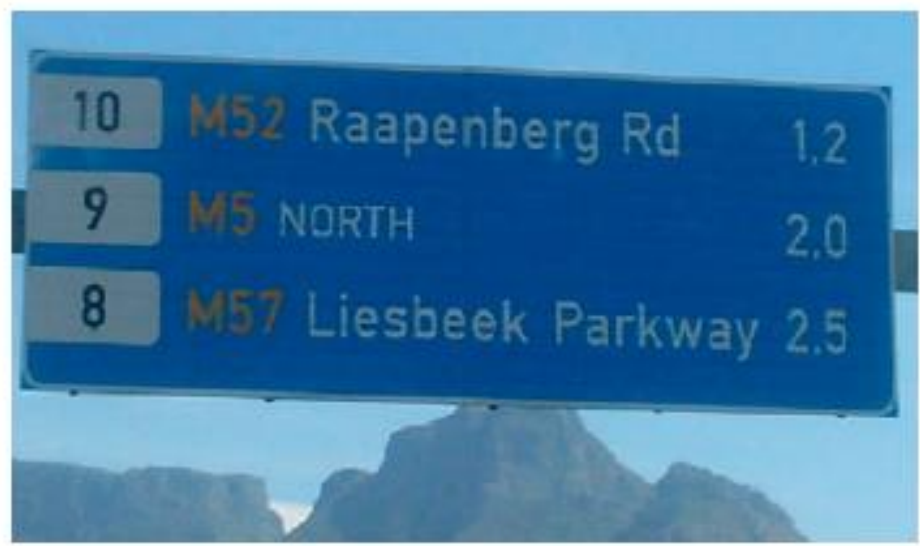

Figure 3. N2 high way.

Note: Picture taken by A. Peck (2010).

These images attest to the city's colonial past and serve as navigators to the city. Their inclusion, regardless of its simplicity, remains evidence of the enduring markers of colonialism on the city.

\section{Signs, appropriation and ownership}

With the diverse ownership of businesses in Observatory's Lower Main Road, the appropriation of space and the production of signage is distinctly localized with interesting (and novel) approaches to the landscape, such as deliberate brand anonymity (discussed later) by transnational African business owners. As all of the signs were found in Observatory, references to global brands are seen as signs of globalization, with reference to the manner in which the global is taken up by the local, in particular the appropriation and resemiotization of Observatory signage and spaces by a diverse constituency. The signage below was uncovered in a shop owned and run by two unrelated Chinese business owners. As seen with the "Asia Supermarket Sushi and Thai Take Away" sign below, there are Chinese, Thai and English languages visible on this sign:
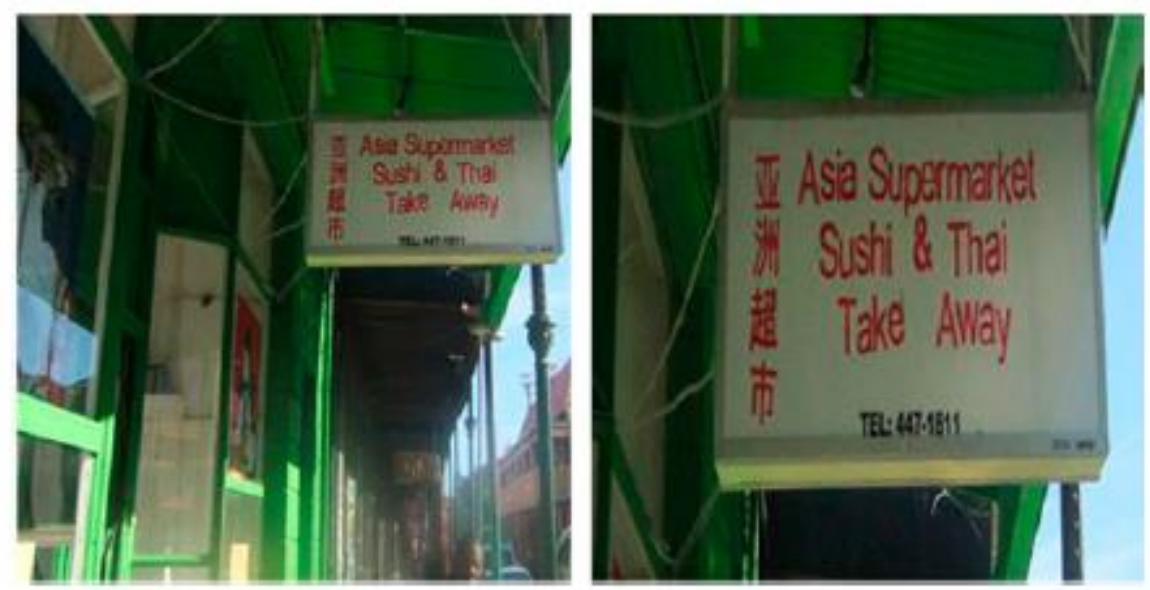

Figure 4. Asia supermarket Sushi and Thai take away.

Note: Picture taken by A. Peck (2009). 
What is interesting about this sign is that the claim to "ownership" of the space is through use of (globally recognized) Chinese and Thai scripts and localized English text as well as graphic illustrations of Chinese women (one is seen on the left backgrounding this picture). The windows have two large posters of traditional "Chinese" women with long black hair and fans in their hands. These posters shape the traditional Chinese appearance that readers come to associate with China and more recent with Chinese stores. The colours on posters are dominated by red, black and white. This is similar to the colours used on the store sign. This specific colour choice is a characteristic feature of mainstream Chinese signage. The use of these traditional colours and artefacts may be considered as a strategic business tactic used to bolster its global "brand" identity in Observatory. As Molokomme (2011) argues, Chinese businesses have learnt that people associate bargain shopping with Chinese signs. In fact, consumers may not even care about what the signs actually mean. Arguably, a focus solely on supposed language errors in signs on the LL may detract from a profound analysis.

For instance, there is an unusual combination of "Asia" and "Supermarket" in "Asia supermarket" which is inconsistent with Standard English. This is because two nouns are placed side by side, which means that the noun "Asia" is used in place of an adjective like "Asian". Also the word "supermarket" is a misnomer in that the store does not supply a large variety of stock as found in conventional supermarkets. This store was only in the business of selling Asian cuisine. The type of English described here may be written off as errors and indicative of what Blommaert et al. (2005) have called "peripheral normativity". However, moving beyond the view of English as simply having "peripheral norms" placed upon it, this study looks at English as localized by the community in which it is located. A shift away from concepts of "peripheral normativity" and "centre English" allow signs and texts to be read in relation to their ability to reach their communicative goal as opposed to a linguistically puritanical analysis of "error counting". In any case, the draw card is more the Chinese characters that identify the shop as Chinese owned than the English phrases. It is unlikely that lovers of Chinese cuisine will be put off by the "grammatical errors." Months later the shop was taken over by another Chinese owner. The new owner claimed spatial ownership through redesigning and re-signing of the signage as shown below:
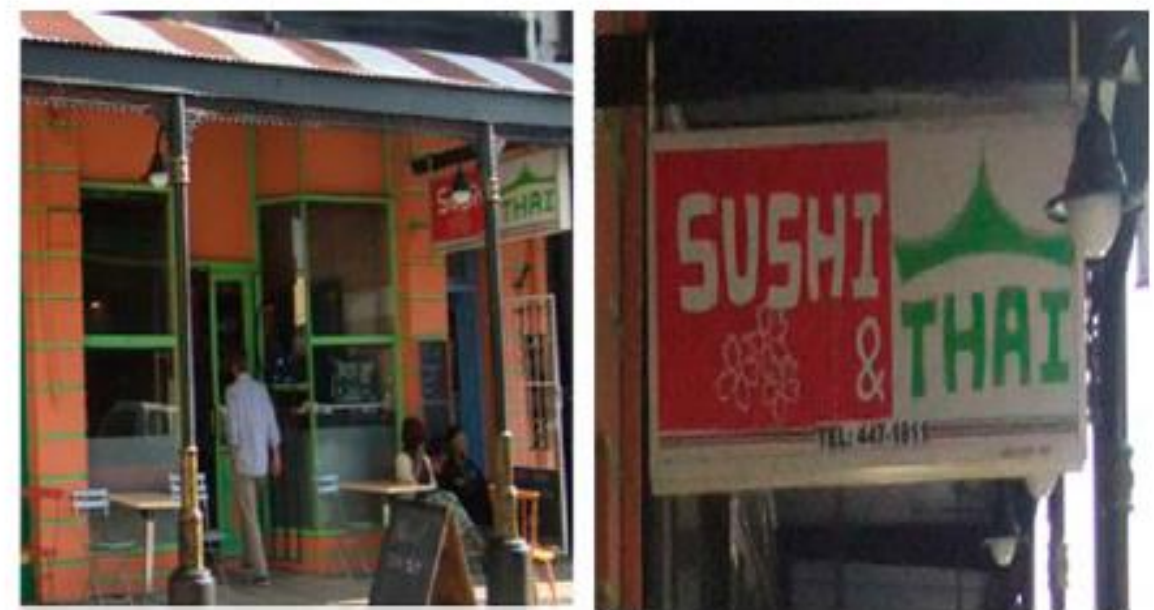

Figure 5. Sushi and Thai.

Note: Picture taken by A. Peck (2010). 
The most glaring difference between the first and second sign could be seen with the reduction of words on the sign and the change in colour. Words on the sign were reduced from seven (Asia Supermarket Sushi and Thai Take Away) to three (Sushi and Thai). There is also a complete erasure of the Chinese inscription originally placed on the left margin of the sign. Here the words "Sushi" and "Thai" were retained from the original sign. Colours on the sign no longer followed the well-known "traditional" black and red, but rather included bright red and neon green. The effects of these changes are twofold: the sign is "uncluttered" and visually more prominent; and second, the sign appears more modern and sophisticated. Apart from the sign itself, the windows of the shop had changed, with misted glass replacing the previous traditional Chinese poster used earlier. Elements which reveal "locality" can be seen with the employment of symmetry on Chinese signage (cf. Leeman and Modan 2010). On the sign, the positioning of the two words "Sushi" and "Thai" are located diagonally across from one another, with each side taking up an equal amount of space. Symmetry is also further emphasized with each half of the sign filled squarely with two different colours. In addition, the two illustrations of flowers (with "Sushi”) and temple (with “Thai”) are also located diagonally across from each other which further emphasize symmetry. In essence, while there is evidence of this sign appropriating a global brand (through word reduction and erasure of Chinese script), it has also simultaneously managed to maintain a sense of locality through symmetry. By emphasising the global, the restaurant lost its core appeal, which is that it is local Chinese restaurant. The owner quickly became aware of this as he felt that it did not stand out enough as an authentically Chinese sign, and therefore, he changed the sign once again. The new signage ensures that all that read the LL know who owns the space. As seen below, the latest remodelling of the sign reveals the identity of the owner "Mr Lin", as well as the re-inclusion of the Chinese script and the addition of a Thai script:

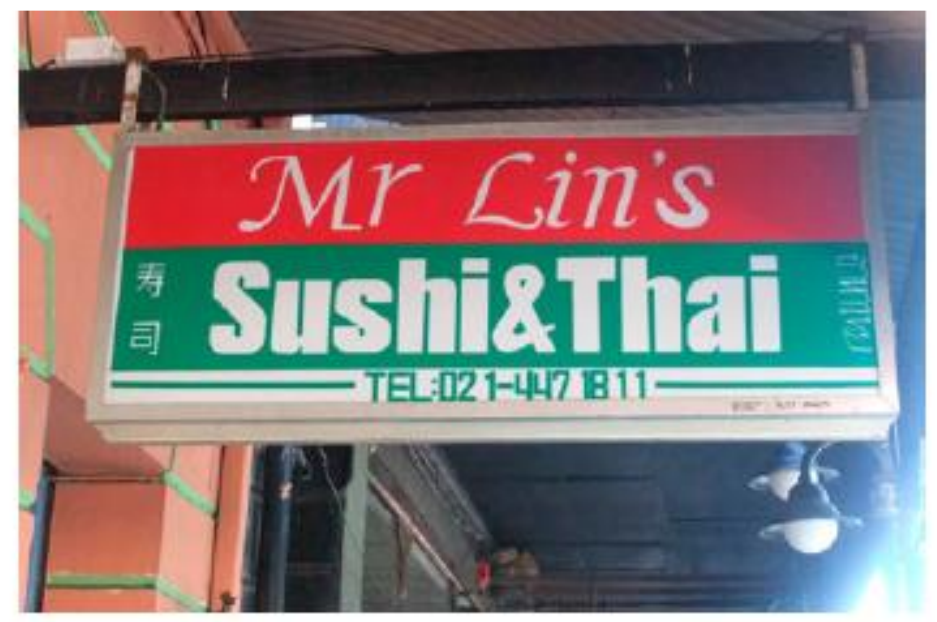

Figure 6. Mr Lin's Sushi and Thai.

Note: Picture taken by A. Peck (2012).

The inclusion of the name "Mr Lin" was a strategic move by the owner of the same name who felt that the community of Observatory would frequent his restaurant more often as they knew him personally (by name). Writing his name in English, however, is at odds with traditional Chinese signage as Lou (2007) notes that “...Chinese establishments often display their names more prominently in Chinese than in English ..." (Leeman and Modan 2010, 349). Mr. Lin's preference for using the English code to announce ownership and familiarize his shop with Observatory patrons reveals his business 
strategy, where English is both communicative (can be read) and symbolic (customary to use family name on signage).

Also, in a globalized world where Asian Restaurants can be owned by a person of any nationality as long as they have the finances and resources to run the business, the reinsertion of the Chinese script (meaning Sushi on the left) and the addition of Thai script (meaning Thai food on the right) are also deliberate and an attempt to claim Asian authenticity. The two scripts flank "Sushi and Thai" thereby creating the customary symmetry associated with Chinese signs. The fonts are also unusual with "Mr Lin's" written in a more romantic font which contrasts with the block font used for "Sushi and Thai". Although the owner did not speak Thai, he obtained the script for the sign from a previous employer. Ultimately, the owner believed that the new sign (including his name, Chinese and Thai script) combined to form a familiar and authentic Asian sign. Asked why he did not include Xhosa or Afrikaans words on his sign he stated "everybody speaks English". The owner admitted that both the Chinese and Thai script fulfilled a symbolic function in Observatory (cf. Leeman and Modan 2010 on their work on the symbolic economy of Chinese script in Washington). Through changes to the sign Mr. Lin manages to constitute a link between his place of business, his identity (Chinese owner) and his seemingly interpersonal relationship with many of his patrons, and to claim ownership of the space.

The claim and appropriation of other previously white spaces is further seen with "African Access Internet Café":

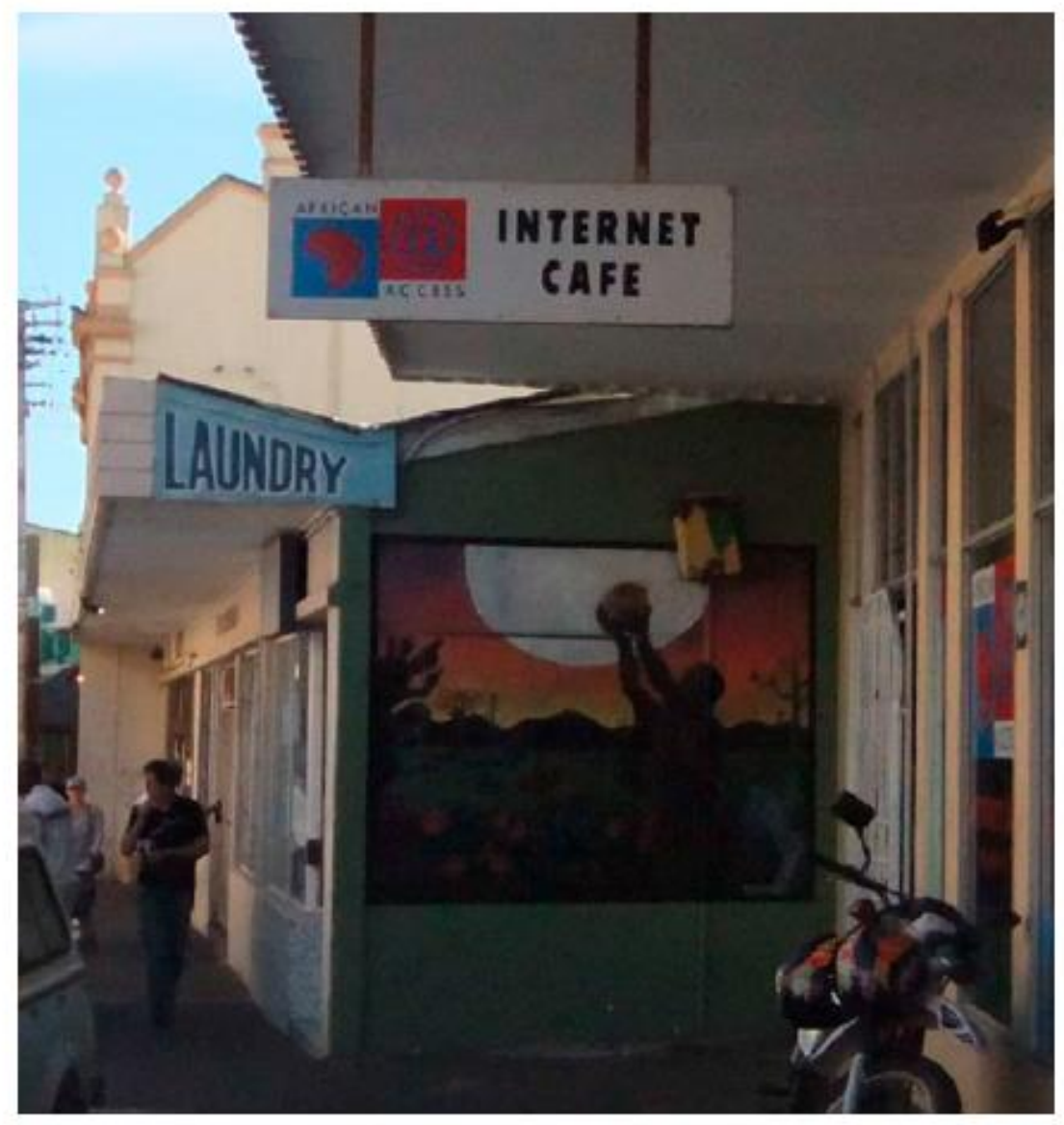

Figure 7. African access.

Note: Picture taken by A. Peck (2009). 
The sign shows a map of the African continent beneath the word "African" on the left side. On the right, there is an @ symbol which denotes technology and the World Wide Web. Beneath the graphic, we see the word "access", which may be understood in terms of internet access, but also access into the world of Africa. The colours used in this sign are not consistent with the natural hues employed in other African signs on LMR. Instead, the bright blue, red and white colours of this sign are indicative of normal commercial colours that is, American flag, Microsoft and IBM. Whereas other African-owned shops on LMR use different colours and textures to portray their Africanness, signage here appears to substitute the use of colour with the word "African"coupled with the image of an African continent. Pertinently, the words "internet cafe" are more prominent as they are afforded more space and a bigger font printed in capitals. The emphasis of the sign is, therefore, drawn more to its indexical value as an internet cafe and less to the emblematic function of it being an "African Internet cafe".

The emplacement of the mural straight ahead of the "African Access" sign enhances the African image of the internet café. One of the informants stated that the mural was painted by an independent artist and was not commissioned by African Access. Nevertheless, the mural does function as a fortuitous sign which creates a distinct African ambience.

On entry into African Access the African mask on the back wall is an explicitly African artefact which is atypical of South African culture. These types of masks are reminiscent of "tribal" South-Central and West African masks. However, although this store has put a lot of effort into creating an African image, the emplacement of the advertisement board at the entrance of the internet shop displays only European and Asian flags and appears to "sell" Africa as a "cheaper" option than Europe.

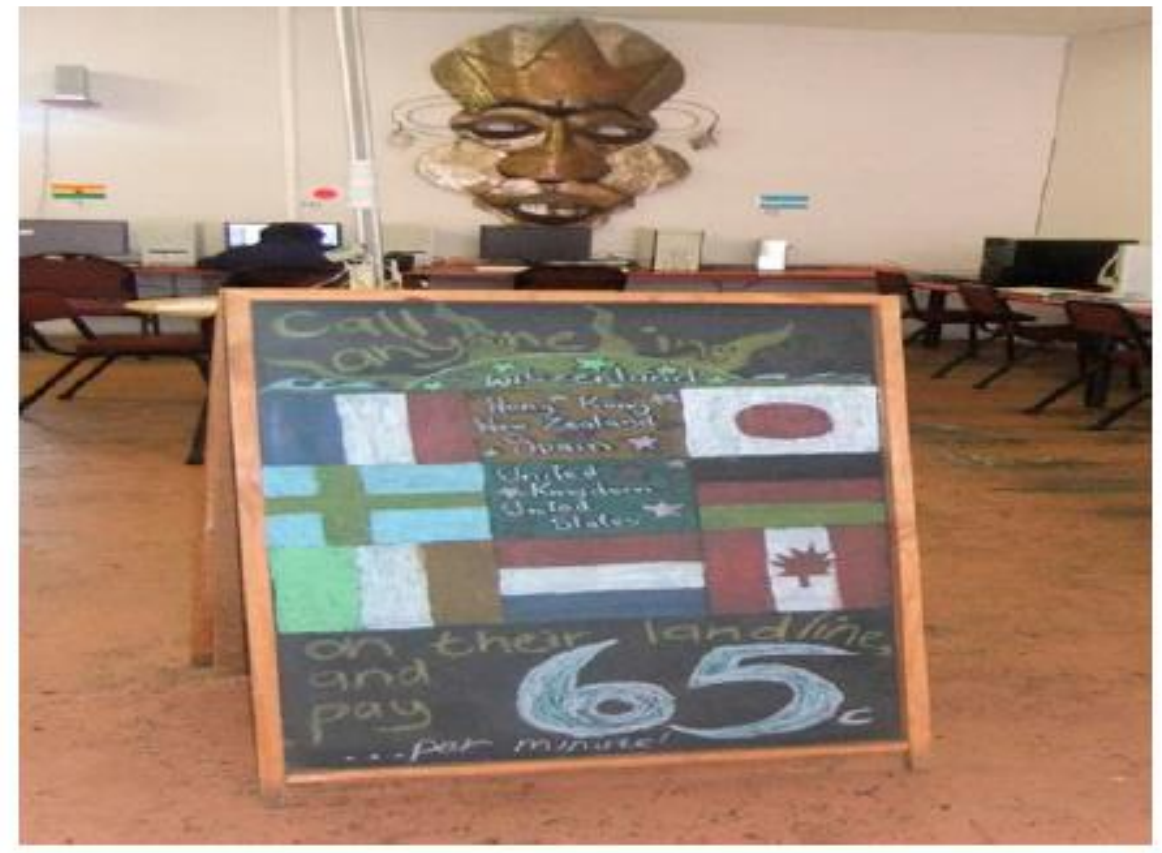

Figure 8. Notice board.

Note: Picture taken by A. Peck (2010). 
The board reads:

Call anyone in: Switzerland, Hong Kong, New Zealand, Spain, United Kingdom, United States on their landline and pay 65 c...per minute!

Rationally, one can deduce that a large number of customers at African Access are European and are residing in Observatory and experiencing "Africa" in LMR. Although any tourist experience comes at a price, this experience of Africa as displayed on the sign board emphasizes the affordability of calling from Africa. Therefore, Observatory's "Africanness" is seen as a commercial selling point in which the "rainbow nation" is positioned and sold cheaply by African Access, and it is also a means by which others claim ownership of previously white owned space.

\section{Appropriation and transformation: case of Ezithebeni Braai Lounge}

A particularly illuminating illustration of transformation and appropriation of space is observed through an analysis of a particular "black" club in Trump Towers, at the end of the "the African corner" of LMR. The "African corner" is situated at the end of LMR and Trill road in the Trump Tower. This area has been labelled by some as "the African corner", due to the vast number of Black patrons and businesses. Over a four-year period, Ezithebeni Braai Lounge (EBL) displayed an abundance of sociolinguistic transformation on its signage. The manner in which this club constructs its Africanness and performs its territoriality is analysed here.

Signage from this site was captured just prior to other signage analysed here, commencing at the end of 2008 and ending in 2011. "Ezithebeni Braai Lounge" captured interest as the only shop on LMR which incorporated the three official languages of the city. This means that, it was the only sign on LMR which showcased English, Afrikaans and Xhosa. The sign and space became even more intriguing as time passed and with each of the subsequent name changes. The name-changes, which appeared to coincide with changes in patronage and outer window transformations affected the "talk" around the changing social dynamics of the club and the changing perception of EBL from an "African" club to a "drug/dangerous" hive. Language and placement of signs are therefore not deemed incidental, and are in fact seen as important indicators to look out for when assessing the appropriation and transformation of space. As argued earlier, language choice on signs may be indicative of the languages that people speak, but it may also have symbolic meaning. Signage on the club specified here changed over the fouryear period of fieldwork and the name changes are provided as follows: Ezithebeni Braai Lounge (end 2008), Ezithebeni Braai Longitima (mid-2009), Ezithebeni Braai Mambo Spotlight (2010) and Ezithebeni Braai Lounge (2011). Notably, throughout the changes to the signage the ownership remained unchanged, but to some of those interviewed, the space changed from an innocent African club to a dangerous den of drug lords.

\section{Language contact and hybridity}

When EBL was first established, it catered for a wide range of people and their shop sign, written in Xhosa, Afrikaans and English, and seemed to convey the inclusiveness of this space. The original shop sign was a combination of Xhosa ("Ezithebeni" meaning "platter") + Afrikaans ("Braai" meaning "barbeque") + English (Lounge). The sign was situated on a painted brown bone with the shop's number directly beneath it. At the time 
of research, the club was considered more of a pub plus restaurant and observations of club patrons showed there to be a diverse patronage.

At the time, Jade (a young Zimbabwean waitress at EBL) stated that the restaurant had a largely black clientele and would play all types of music: particularly House, Zimbabwean, R \& B, Country and Soul. The Africanness of EBL emerged not only through signage, but was also observed through the types of music, food and overall ambience of the club. The transformation of the club from an unknown space to one appropriated by "Africans" becomes apparent in the review of the club proffered by another Zimbabwean contact named Morris who had had only positive things to say about EBL:

Ezithe [EBL] is lekker, it's lekker because they play Congolese music, pap and meat, so usually Congolese, Nigerian, coloured [frequents EBL], actually "cause I been scared, I used to stay in Delft..."

Interestingly Morris finds EBL to be a comfortable space in which to interact with coloureds - a group which he had previously been frightened to encounter in his home in Delft. Delft is a poverty-stricken coloured township in Cape Town and is often associated with gangsterism and violence. For Morris, EBL had become a space in which novel experiences with an unlikely group could occur and it is through this transformation and appropriation of the space that EBL changed the landscape of the social scene on LMR.

This restaurant and club would often be found with signboards placed outside showing the African dishes available. An example of the menu board is provided below:

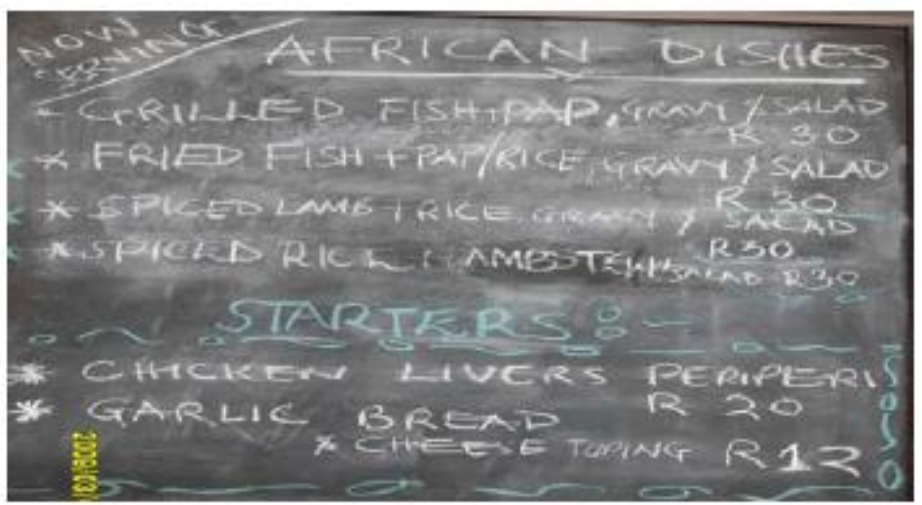

Figure 9. Menu board.

Note: Picture taken by A. Peck (2010).

The menu board reads:

Now Serving/African Dishes

Grilled fish + pap, gravy \& salad R30

Fried fish + pap/rice, gravy \& salad R30

Spiced lamb + rice, gravy \& salad R30

Spiced rice and lamb stew \& salad R30

Starters:

Chicken livers peri-peri R2O

Garlic bread \& cheese topping R12 
Interestingly, the dishes themselves have also become recontextualized as the fish advertised at this restaurant is not typical freshwater fish found and sold in landlocked Africa such as Zimbabwe, but rather the local fish (hake and snoek) found in Cape Town. Nevertheless, this fish is prepared in an African way with "pap" [hard porridge] and "rice". The effect of "braaing" the fish also speaks to hybridity in culinary tastes and foodscapes through the merging of local (South African) and (other) African fusion.

\section{Opening context}

In mid-2009, the sign changed to Ezithebeni Braai Longitima, which now meant that the language choice changed slightly to Xhosa + Afrikaans + Hybrid English. It was deduced that the word "longitima" may have been the phonetic equivalent of the English expression "long time". The words were written in brown text on a yellow background shaped as a bone or platter. The colours chosen can be described as neutral colours which are typically used to depict African heritage. An African heritage (as tied to the DRC) was suggested by some informants as they believed that "longitima" was an urban Lingala word meaning "chill". However, this assumption could not be confirmed irrefutably. Notwithstanding this incertitude, Lingala music has definitely become recognized and widespread over much of Africa. Previously, Cape Town was thought of as a Xhosa territory, and thus believed to have been largely unaffected by Lingala music and culture. Nevertheless, while EBL gained popularity as an overtly African club in LMR, their existence was not welcomed by everyone in Observatory. In fact, businesses and clubs in the African corner became a regular discussion point at the Observatory Civic Association (OCA) ${ }^{2}$ meetings and were minuted (November 2009) as:

4.6 In collaboration with the $\mathrm{CPF}$, a database of all the establishments without health and safety-, liquor- and business licenses will the [be] compiled.

A meeting with the OCA and the Community Police Forum (CPF), as well as some of the business owners in LMR, took place soon after. The meeting pointed to the shortcomings of some business on LMR, but no specific resolution was made on EBL. However, following temporary closure for renovations, EBL reappeared with not only a change in the language choice on its signage, but also a complete overhaul of its outer aesthetics as well.

\section{Second recontexualization}

EBL's second transformation came with the name change to Ezithebeni Braai Mamba Spotlight. "Mamba" is a short form for the Black Mamba snake. The African-related theme (of being wild and untamed) is continued here, as seen on the following page.

The continued transformation and appropriation of space can be seen with the expanded colour range to include red and blue on a lime green background, as well as the name change and even the outer windows. The windows now have a misty glaze which obscures vision into the club and contributes to it being perceived as more private and discreet than before. These changes further exacerbated discourse around drug dealing and crime at the club. In fact, by the time the third name change was realized, the change in the social dynamics of the patrons was remarked upon by many. Another Zimbabwean informant believes that EBL has become "too Congolese" and is

\section{http://repository.uwc.ac.za}


no longer "cool". He said that he felt that they no longer catered for their "African brothers".

While EBL was being transformed once again, there was talk about crime by OCA members and informants (black business owners). The resulting discourse led to a meeting of the local police (action) and the construction of a specific "reality" in which many of the (black) businesses in the "African corner" were conflated with crime and drug dealing. Iedema describes the creation of "facticity" from local talk as directly related to the "construction of reality".

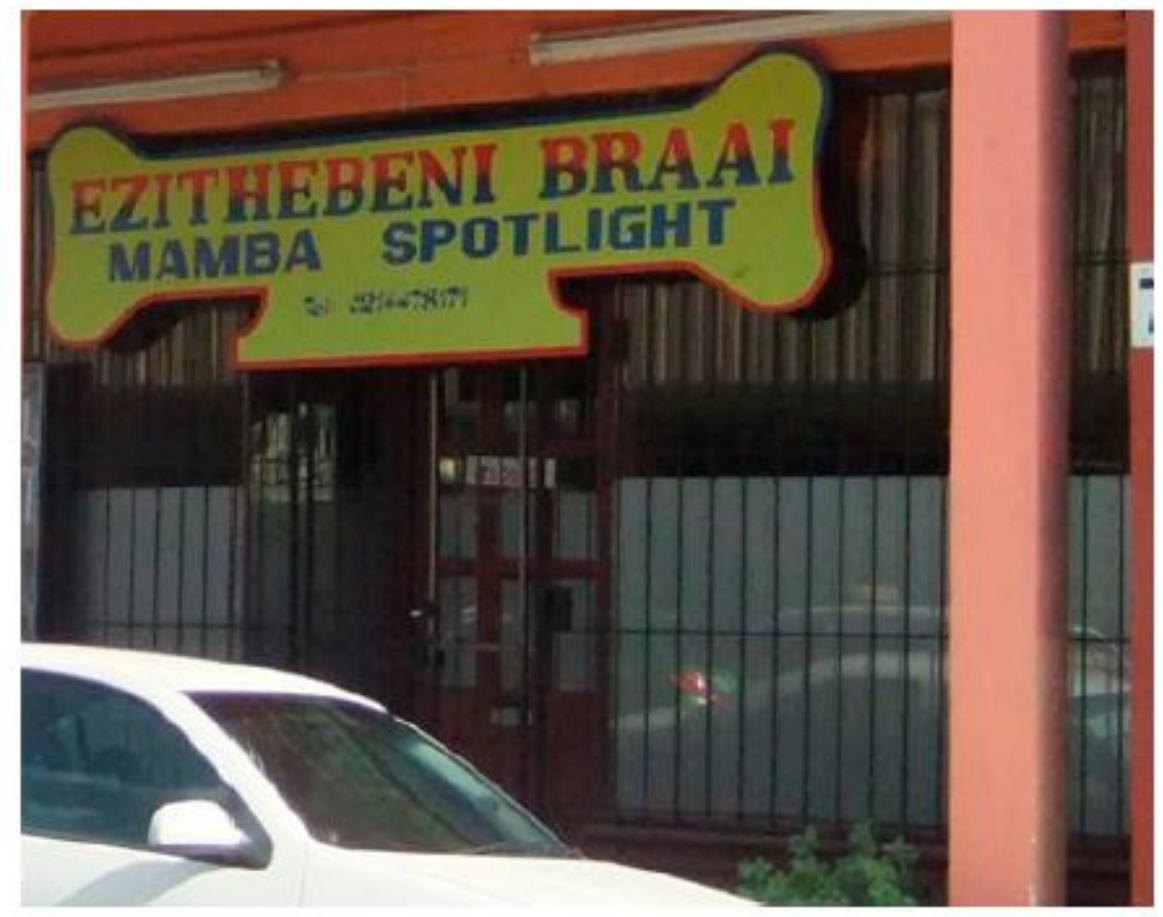

Figure 10. Ezithebeni Braai Mamba Spotlight.

Note: Picture taken by A. Peck (2010).

Drawing on Mehan (1993) he states “...with each step the process reconfigures the situation which it posited as its origin: an increasing number of people become involved; relevant meanings are committed to minutes, reports and files; letters and other forms of correspondence summarize and thereby "authorize" those meanings, and so on. Thanks to that increasing distance from its origin, each recontextualization adds to the "weight", the institutional importance, the authority, in short, the "facticity", of what is said and written" (Iedema 2003, 41).

The meeting between CPF, OCA and business owners in the African corner can be said to have culminated from a journey of "talk" to documented "facts". This "talk" at OCA meetings became minuted, and from these minuted meetings emerged enquiries and calls to institution bodies and business owners, which led to the eventual meeting itself. With each recontextualization of the perceived "problem" also came extra "validity" and "facticity" of the problem. This meeting can be seen as a power play about ownership of a particular space in which speculation, fact and fiction became blurred. 
The change in the signage represented different stages of appropriation of the African corner by Africans. The transformation and appropriation of an African territory proved to put into motion many other seemingly separate and isolated elements of quotidian life in the African corner. The power of discourse and organization (monthly meetings and collaborating with the police) resulted in speculation of criminal activities coming to a head. In this way the "facticity" (Iedema 2003) of what was speculated, discussed, minuted and presented, resulted in the increased importance of the OCA. Speculated criminal activities resemiotized as a "facticity" represented a challenge to the legitimacy and authenticity of the business being run at the African corner, which in turn served to challenge African ownership of the African corner.

\section{Third recontextualization}

The most recent version of the sign to date reveals the sign coming full circle. The fourth remodelling of the sign is provided below:

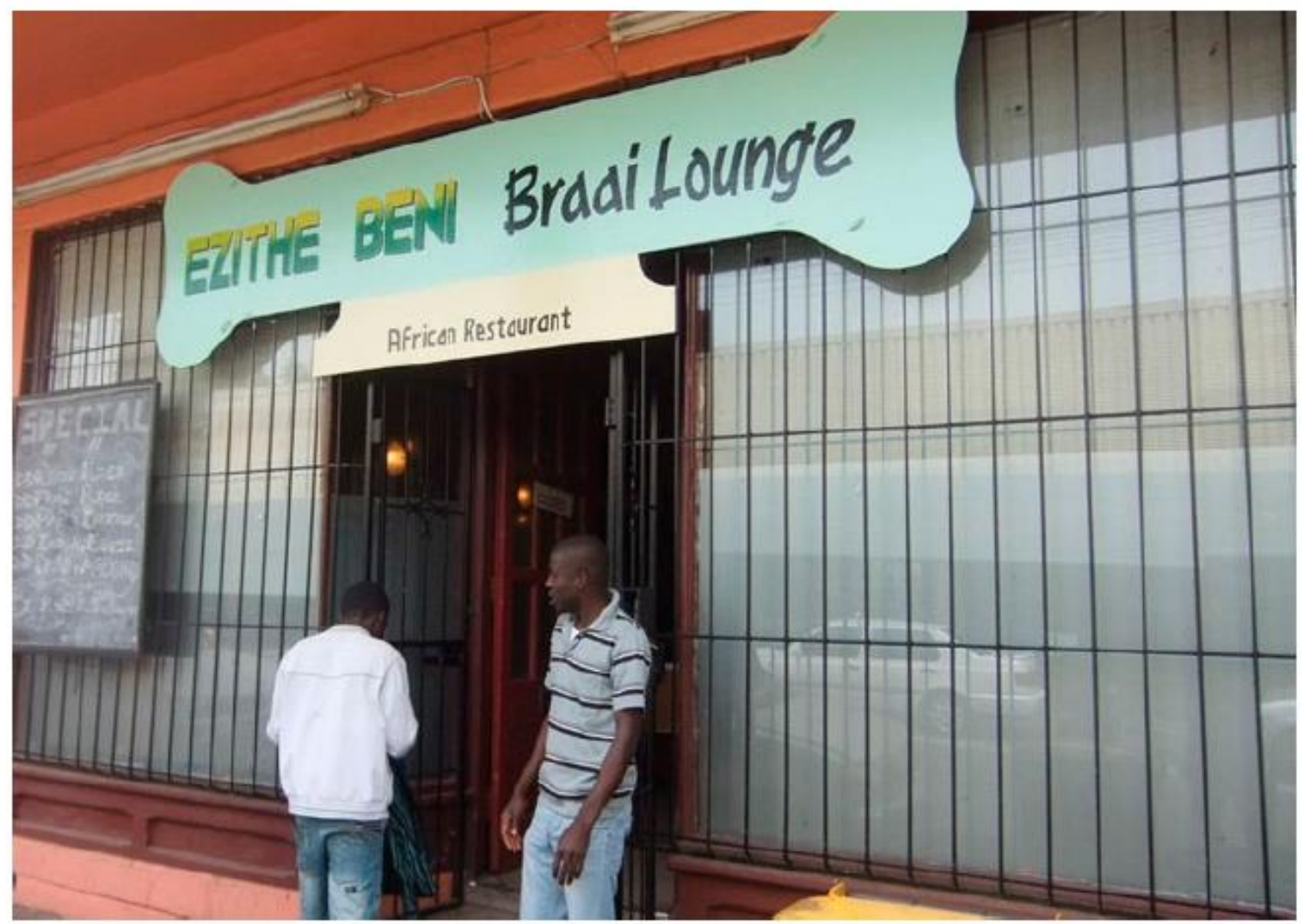

Figure 11. Ezithebeni Braai Lounge.

Note: Picture taken by A. Peck (2011).

While the splitting of the word "ezithebeni" into "ezithe" and "beni" does not appear to fulfil any evident linguistic function, the addition of "African Restaurant" at the bottom of the sign effectively replaces the contact number for the store. The removal of a store telephone number is somewhat peculiar, in that, the restaurant businesses usually display contact details so that potential customers can reach them to book tables and make enquiries. Therefore, the removal of the telephone number may mean going back to African tradition where there is preponderance for the oral message, which could prove problematic in the modern technology driven age. The shop windows have also been further blocked up, and therefore, there is even less visibility into the club, which also contradicts common wisdom of Africa being a sunshine hub. 
In sum, we see EBL refracting further and further from a public space to a private, but purportedly African one. The previous manifestation of this restaurant as a multilingual space (wherein the opportunity to create a space of difference was purported) has now for some participants become a "Nigerian" club, which they considered as dangerous.

In short, through a mix of ethnographic fieldwork and a multimodal analysis of the LL we see the sociohistorical trajectory in the recontexualization of EBL. This phenomenon can be seen with EBL starting out as a braai space (patroned by blacks and coloureds), then later refracting into a more private space (seen through name change and later the semiotic process of screened glass panes, and then refracted even further by its perception of housing drug dealers). Although the patrons may have stayed the same, the aesthetic changes made to the signage and windows, as well as the discourses of fear and suspicion resulted in this space refracting from a public space to a more and more private space, which some perceived as dangerous.

Another African shop which roused interest was that of the Somali-run shop which, unlike EBL exhibited a district inclination to conceal its identity or brand.

\section{Brand anonymity in LL}

While it is clear that some transnational owners (as seen with EBL) celebrated ownership openly and use it as a marketing strategy, other groups appear to shy away from the overt use of signs that might identify and link them to a particular space. An example of a group that obviates from foregrounding their Africanness is that of the Somali store in LMR. Unlike the Asian and African groups mentioned above, the Somali shop employs no African images or languages. Below is a graphic image of the Somali-owned shop on LMR, named VIV Supermarket:

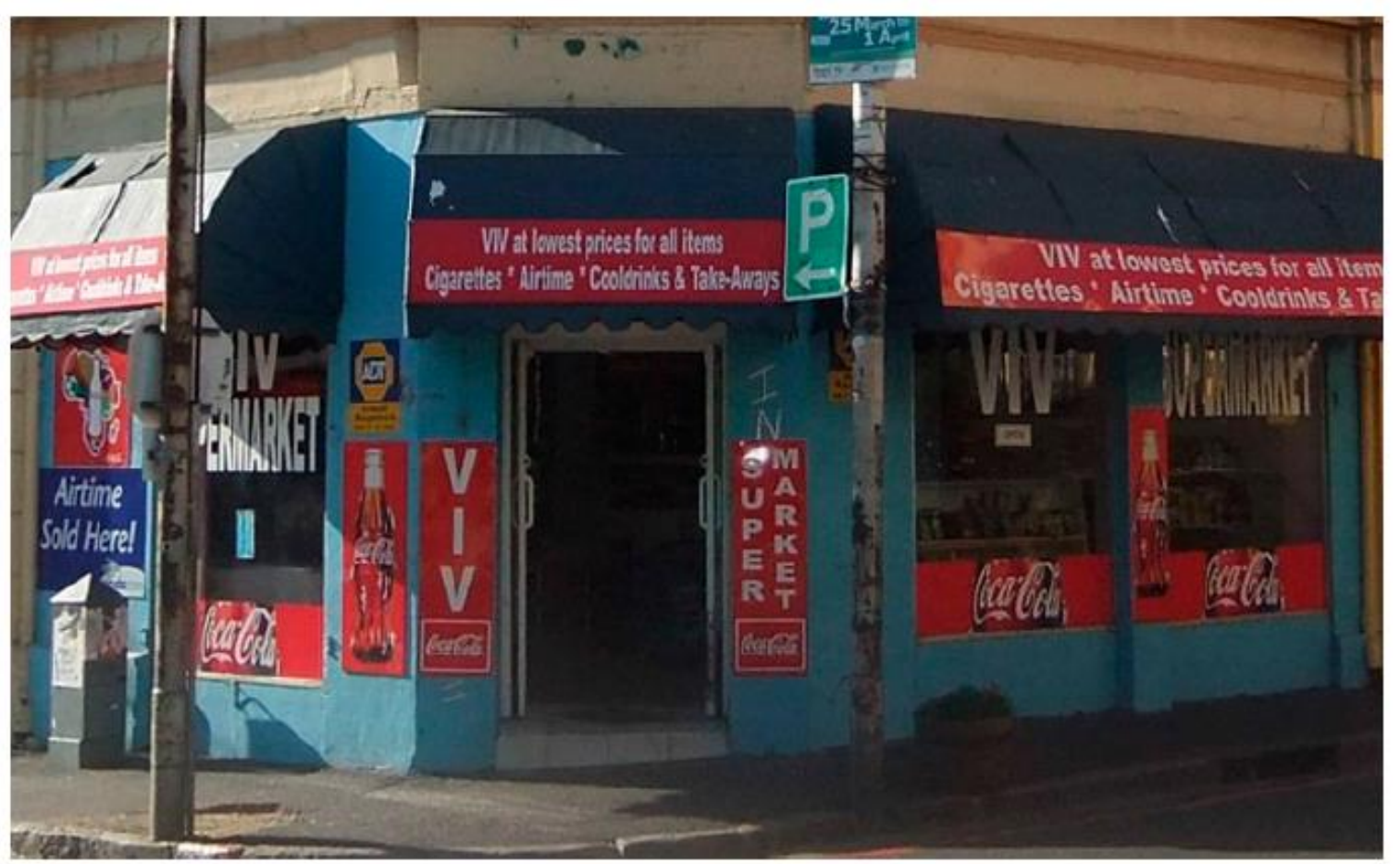

Figure 12. VIV supermarket. 
The shop above is called "VIV Supermarket" and unlike many other shops in LMR, which painstakingly customize the design of their stores to project a clearly African image, no such attempt was made by this Somali business owner. At first there appears nothing in the design of the shop windows or signage which makes this store stand out. "VIV" reads like an innocuous (short form of an) English name. However, it is argued later that this is in itself a key indicator of design making. Whereas previous signage shows Africanness being celebrated openly in Observatory, the exterior of this shop appears to be unmarked by any African signage, art and texts. On the one hand it may be argued that their goal was not to index identity in the usual social sense, but to index a corporate identity which transcends local or national identities and allows for greater anonymity. On the other hand, the anonymity of the branding may also stem from a keen awareness of the vulnerability of Somali traders in South Africa. Somalis have borne the brunt of xenophobia attacks in South Africa and their shops are often singled out and vandalized (cf. Mnyaka 2009).

The Coca-Cola branding coupled with the sign "Airtime sold here" are all generic signs. The sign on the right of the entrance reading "super" and "market" was pasted over the previous owner's paintwork. The previous store was called INDULGE and the "I" and "N" from "INDULGE" can still partly be seen on the right-hand side of the shop door. The words "super market" are used in the same way as in the earlier Asian sign discussed previously. However, the use of "super market" here can be understood as shops which are relatively small but diversified in their stock. There are many reasons why the owner may have chosen to separate the words (perhaps as a form of boasting or irony), but either way the separation of the words can be seen as local usage of English by African business owners.

This "supermarket" can be described as a small convenient store, stocking essential groceries, airtime and cigarettes. The store may be perceived as lacking planning or creativity on behalf of the shop owner as seen from the lack of personalization of the store. At the same time this may itself be regarded as a keen business strategy. With the store situated amongst the gaily painted and intriguing shop fronts of LMR, the business owner appears to rely on the world-renowned Coca-Cola branding to propel it from obscurity, whilst performing a dual function of concealing its Somali identity from the landscape. This may seem paradoxical, but unlike brand association (association with a brand so as to enhance one's own personal brand), we argue that this type of branding may better be understood as "brand anonymity", a neologism which combines the association with a brand so as to conceal a supererogatory facet of one's personal makeup. Intriguingly, the deliberate concealment of the Somali trader's identity with global brands has become commonplace in Cape Town, and in and of itself has become associated with Somalis shops.

Notwithstanding the clear flouting of personalizing commercial signage design on LMR, "VIV Supermarket" does indeed practice territoriality of its space as seen on entry into the store. The shop owner did not remove the previous owner's paintwork which can still be seen when looking at the pink paintwork that lines the windows. The 
emplacement of a TV above the exit to the store is the act of territoriality as it plays Islamic videos. Pertinently, the emplacement of the TV is positioned for the viewing of the cashier and not the customers. The creative placement of a TV bunny antenna on top of a used coffee container is also unusual in Observatory, as most stores, restaurants and pubs try their utmost to conceal their fittings and fixtures.

In many ways the Somali shop flouts normalized commercial strategies (such as inter alia the customizing of a brand, removal of previous owner's shop décor and the concealment of wires and fixtures) when competing with globally recognized brands in LMR. Due in large part to these idiosyncratic commercial divergences, the Somali shop does indeed reinvent space through the deliberate introduction of township-like products and services. What is seen here is the reshaping of the landscape through their use of creative and elementary business strategies - in a way borrowing from business strategies, which Somalis have effectively used in black townships and moving them into the sophisticated commercial hub of LMR.

\section{Conclusion}

The longitudinal nature of this study has foregrounded the saliency of an ethnographic approach to LL studies, which enabled us to chronicle the trajectory of signs across geographical boundaries, space and time. Thus, LL was linked to social identities, changes in ownership, owner aspirations and perceived clients, as well as forces of localization and globalization. The paper has shown that LL may not only reveal appropriation and ownership of space, but may also function to conceal ownership, in what we termed brand concealment.

The paper affirms recent work showing that languages spoken "on the ground" are not always reflected on the landscape. Case in point is that of Afrikaans and its large- scale absence on the LL. With the exception of cautionary (governmental) signage, very little other Afrikaans was observable on the LL. This phenomenon, taken on its own, may appear to be axiomatic in a typically English neighbourhood; however the census data shows that a large percentage of the neighbourhood speaks the language. This point affirms that the hallmark of linguistic vitality may not always be discursively constructed on the LL. Interestingly, although English was the common denominator on all mixed signs on the LL, there was evidence that it was the localized version of English which was dominantly employed. It is clear that language choice on the LL could not simply be tabulated and quantitatively explicated.

Perhaps of more interest, however, was the manner in which the LL revealed transborder activity through the mobility of people, language and cultural and business practices. In particular, Mr Lin (the Chinese restaurant owner) initially thwarted tradition by opting for prominence of English and not Chinese script on the LL. However, he later not only accentuated Chinese and Thai scripts, but he also kept to the customary display of his family name in English as is often done on Chinese owned shops and businesses. For an average South African reader the Chinese and Thai scripts are indistinguishable and are read as "Chinese," but they will pick out the owner's name as Mr Lin. Thus, Mr Lin kept with some traditional signage techniques such as the inclusion of the owner's name in English, Chinese script and the addition of Thai and the use of symmetry, therein 
effectively towing the line between "traditional" and "new age". This shows that the owner was keenly aware of "what works" in Observatory and also recognized the importance of the global Chinese brand, personalization and localized social networks.

A longitudinal study of EBL's transformation showed not only spatial appropriation, but also the mobility of semiotic artefacts and cultural symbols such language, music and cuisines across national borders. Congolese ownership was publicised among other semiotics through Lingala music originally from the DRC.

Within the Somali store, the merchandizing and stocking of very essential food items, suggest a bringing in of services and goods typically found in townships and previously unexpected in the middle-class and sophisticated LMR. More interestingly was the need to acknowledge that not all signage may be employed for its typical usage that is, brand association. The Somali shop, with its overt display of the globally recognized Coca-Cola branding, needed to be situated into the South African sociocultural setting. This group is often the target for cruel and violent attacks all over Cape Town and even on questioning, remained stubbornly unwilling to discuss their own identity. Taking the social into consideration has resulted in the need to coin the notion of "brand anonymity" as one borne out of social necessity. In fact, due to the ubiquitous nature of Somali shops with Coca-Cola branding (and a distinct lack of any other personalization), these stores are easily identifiable.

Overall, the socially attuned Asian and African business owners (although vastly different) seem to have effectively permeated the social and geographic borders on LMR. Intriguingly, while Ezithebeni Braai Lounge was willing to embrace and overtly display its Africanism as a key selling point; over time, this choice became constructed as a problem with the place ideologically becoming associated with danger and crime.

Most notably, signs on the LL reveal a predilection towards appealing to European taste through the brokering (selling) of token African cuisine, apparel and culture, not through "centre" English, but through localized varieties of English. Importantly, this study shows that since spaces are always in flux, the "owners" of these spaces are able to change and own space (albeit temporarily until change of ownership). This occurrence also emphasizes the pliability of not only language, but also space and in so doing emphasizes the saliency of human agencies in the reinvention of space and language on the LL. The context behind changes to the LL was significant and only made evident through ethnographic interviews of storeowners and patrons. This supports work by Leeman and Modan $(2010,196)$ which state that “...[T] o understand that writing [on the LL], we need to know the backstory of how it came into being, and of the interests that constrained or enabled the form that the urban landscape ultimately takes."

In sum, we find that Observatory, a neighbourhood epitomizing the imprints of colonial history, succeeds in an especially African manner to hold tightly to the structural remains of a bygone colonial era, while all the same making space for newcomers, different languages, and diverse semiotic practices required for reinventing the landscape. 


\section{Acknowledgements}

This work was made possible through funding by the Vlaamse Interuniversitaire Raad (VLIR) as well as the (South African) National Research Foundation (NRF). The views expressed herein are solely the responsibility of the authors and do not necessarily represent the official views of VLIR or NRF.

\section{Notes}

1. The term "coloured" was coined by the apartheid governments and used to categorize people of mixed heritage. This term is still used in official documentation and in lay conversation.

2. The OCA was established in 2003 and functions as a community association which liaises with local Ward 57 Councillor and the City Council. Their function is to represent the interests of residents and businesses in Observatory.

\section{Notes on contributors}

Amiena Peck recently completed a PhD in Sociolinguistics from the University of the Western Cape, South Africa. Her thesis is entitled "Reimagining diversity in postapartheid Observatory, Cape Town: a Discourse Analysis" and problematizes the notion of a transformed society in the multicultural post-apartheid neighbourhood of Observatory, Cape Town.

Felix Banda is professor in the Department of Linguistics at the University of the Western Cape, where he teaches graduate and postgraduate courses in multilingualism in society and education and technology-mediated business communication and intercultural communication. He has published numerous book chapters and articles in a wide range of peer reviewed journals. 


\section{References}

Backhaus, P. 2007. Linguistic Landscapes. A Comparative Study of Urban Multilingualism in Tokyo. Clevedon: Multilingual Matters.

Bickford-Smith, V., E. van Heyningen, and N. Worden. 1999. Cape Town in the Twentieth Century. Claremont: David Philip.

Blommaert, J., M. Huysmans, N. Muyllaert, and C. Dyers. 2005. "Peripheral Normativity: Literacy and the Production of Locality in a South African Township School." Linguistics and Education 13: 374-403.

Cooper, B., and R. L. Spolsky. 1991. The Languages of Jerusalem. Oxford: Clarendon.

Press. Iedema, R. 2003. "Multimodality, Resemiotization: Extending the Analysis of Discourse as Multi-semiotic Practice. Visual Communication 2 (1): 29-57. doi:10.1177/1470357203002001751.

Jaworksi, A., and C. Thurlow. 2010. Semiotic Landscapes: Language, Image, Space. London: Continuum International.

Kress, G., and T. Van Leeuwen. 2006. Reading Images: The Grammar of Visual Design. New York: Routledge.

Landry, R., and R. Y. Bourhis. 1997. "Linguistic Landscape and Ethnolinguistic Vitality: An Empirical Study." Journal of Language and Social Psychology 16 (1): 23-49. doi:10.1177/ 0261927X970161002.

Leeman, J., and G. Modan. 2010. "Selling the City: Language, Ethnicity and Commodified Space." In Linguistic Landscape in the City, edited by E. Shohamy, E. Ben Rafael, and M. Barni, 182-198. Bristol: Multilingual Matters.

Lou, J. 2007. "Situating Linguistics Landscape in Time and Space: A Multidimensional Study of the Discursive Construction of Washington, DC Chinatown." PhD diss., Georgetown University.

Mehan, H. 1993. "Beneath the Skin and between the Ears: A Case Study in the Politics of Representation." In Understanding Practice: Perspectives on Activity and Context, edited by, S. Chaiklin and J. Lave, 241-268. Cambridge: Cambridge University Press.

Mignolo, W. 2000. Local Histories/Global Designs: Coloniality, Subaltern Knowledges, and Border Thinking. Princeton, NJ: Princeton University Press.

Mnyaka, M. N. N. 2009. "Xenophobia as a Response to Foreigners in Post-apartheid South African and Post-exilic Israel: A Comparative Critique in the Light of the Gospel and Ubuntu Ethical Principals.” PhD diss., University of South Africa.

Molokomme, N. S. 2011. "A Multimodal Analysis of Linguistic Landscapes in and around Botswana Parliament." MA diss., University of the Western Cape.

Montoya-Pelaez, J. P. 1987. "Gentrification in Observatory." Honours diss., University of Cape Town. Observatory Civic Association Meeting Minutes. 2009. Observatory, Cape Town.

Peck, A. 2012. "Reimagining Diversity in Post-apartheid Observatory, Cape Town." PhD diss., University of the Western Cape.

Scollon, R., and S. W. Scollon. 2003. Discourses in Place Language in the Material World. London: Routledge.

Shohamy, E., E. Ben Rafael, and M. Barni. 2010. Linguistic Landscape in the City. Bristol: Multilingual Matters.

South African Constitution. Group Areas Act No. 41 of 1950 http://africanhistory.about.com/od/ apartheidlaws/g/No41of5o.htm. 
Stroud, C., and S. Mpendukana. 2009. "Towards a Material Ethnography of Linguistic Landscape: Multilingualism, Mobility and Space in a South African Township." Journal of Sociolinguistics 13: 363-386. doi:10.1111/j.1467-9841.2009.00410.x.

Young, J. 1998. “A Town in the Suburbs: A History of Observatory: 1881-1913.” Honours diss., University of Cape Town. 